\title{
The Relationship between Academic Motivations and University Students' Attitudes towards Learning
}

\author{
Adnan Tasgin \\ Asst. Prof., Ataturk University, Department of Educational Sciences, Erzurum, Turkey, \\ atasgin@atauni.edu.tr

\section{Göksel Coskun} \\ Ph.D. Student, Ataturk University, Department of Educational Sciences, Erzurum, \\ Turkey,gcoskun@beu.edu.tr
}

The aim of this research is to examine the relationship between university students' attitudes towards learning and their academic motivations. This is a relational survey model study and the population composed of university students studying at a state university. The sample is composed of the university students determined according to stratified sampling method among the related university students. The "Attitude Toward Learning Scale" and "Academic Motivation Scale" were used in the study. According to the results of the study, it was found that the students' attitudes and motivations for learning differ in favor of the females, there was a moderately positive and meaningful relationship between attitude towards learning and academic motivation, and that there was no significant difference in academic motivation as well as in attitudes towards learning of students according to school type. In addition, it was concluded that there was a high and positive correlation between intrinsic and extrinsic motivation and academic motivation, and that there was a low and negative correlation between amotivation and academic motivation.

Keywords: learning, academic motivation, attitude, university students, intrinsic motivation, extrinsic motivation

\section{INTRODUCTION}

Learning paves the way for a community to move forward in the future. The developments that people make, from learning to ingenuity, contribute to new discoveries and inventions of the future generations. Learning involves acquiring and changing of knowledge, skills, strategies, beliefs, attitudes and behaviors (Schunk, 2009). Learning is not only specific to the educational system. It starts a long time before school and continues for a long time after school again. In addition, learning takes place very quickly in a variety of ways in parallel to the school and in very different environments (Pritchard, 2015). How students learn is also influenced by their

Citation: Tasgin, A., \& Coskun, G. (2018). The Relationship between Academic Motivations and University Students' Attitudes towards Learning. International Journal of Instruction, 11(4), 935-950. https://doi.org/10.12973/iji.2018.11459a 
motivational orientations. According to Biggs (1987), there is an important relationship between cognitive processes and motivation orientation. According to Lumsden (1994), learning environment has an important influence on motivation. For example, a supportive classroom environment in which a student feels that he / she is valuable, increases his / her willingness to participate in his / her learning process. According to Lepper (1988), the different achievable learning tasks, which help the students see how information and skills are used in real life, can also increase motivation. Motivation has an important effect on learning attitude and learning behavior (Deci \& Ryan, 1985; Fairchild et al., 2005; Ryan \& Deci, 2000; Vallerand et al., 1993).

Motivation is an important variable that affects all phases of learning and practice. Motivation is an explanatory concept that helps us understand why people act in certain ways (Schunk, 2009) and it's mostly an inner state that awakens, directs, and sustains behavior (Woolfolk Hoy, 2015). Motivation is a triggering power for learning. Lack of motivation means lack of mobility and therefore it means difficulty in achieving the desired goal (Demir \& Budak, 2016).

Deci et al. (1991) consider motivation as intrinsic, extrinsic and amotivation and see intrinsic-extrinsic motivation as a harmonious whole. When students have intrinsic motivation for learning, they tend to enjoy the learning experience, develop a deeper understanding of the content, and be more persistent in their goals (Carlton \& Winsler, 1998; Merlin, 2003). According to Forsyth and McMillan (1991), intrinsic motivation is an important aspect of teaching and learning. Goal orientation is a motivational variable that explains why students are willing to engage in an activity they are willing to learn (Song \& Grabowski, 2006). Extrinsic motivation occurs in activities done to achieve results. Extrinsic motivation, unlike intrinsic motivation, focuses on the benefits of activity rather than enjoyment (Deci \& Ryan, 2000). Amotivation is expressed as the failure of the individual to understand the conditions between his actions and his results (Ratelle et al., 2007). Amotivation occurs when students individually do not receive positive feedback with their performances or fail repeatedly (Deci \& Ryan, 1985).

Students who are motivated to learn participate in the course and carry out activities such as repeating the information, associating it with previously known information, and asking questions. Motivated students make more effort than they give up when they face a challenge. They do tasks without asking themselves; read books in their spare time, solve problems and puzzles, and work on computer projects (Schunk, 2009).

Another dimension of the motivation is the concept of academic motivation. Academic motivation is a fundamental determinant of success and academic performance (Green et al., 2006; Linnenbrink \& Pintrich, 2002). Academic motivation is important because it positively influences students ' approach to academic tasks, their spending of time and energy, and their efforts to complete academic tasks (Lindner \& Harris, 1998; VanZileTamsen \& Livingston, 1999). It is generally accepted that academic motivation is useful for learning and success. Although non-motivated students tend to move away from school, students who are academically motivated spend much more time in their classes (Pintrich, 2003). 
There are many researches on motivation in the literature. When the results of these studies are examined, it was found that motivation has a significant impact on students ' educational achievements (Lai, 2011; Sakač, 2008; Velki, 2011); extrinsic motivation factors do not have high values for learning motivation and academic achievement (Benabou \& Tirole, 2003; Velki, 2011); there is a positive relationship between intrinsic motivation and students ' learning achievements and self-efficacy perceptions (Ames, 1992; Gotfried 1990; Pokay \& Blumenfeld, 1990); there is a positive and meaningful relationship between academic motivation and academic achievement (Amrai et al., 2011); motivation, self-regulation strategies and level of knowledge distinguish successful students and unsuccessful students (Vanderstoep et al., 1996); students with extrinsic motivation have lower academic achievement than students with intrinsic motivation (Afzal et al., 2010; Bye et al., 2007; Daniels, 2010); students who use extrinsic motivation only expect awards and high grades (Lei, 2010); autonomous academic motivation positively determines good working strategies and greater working effort (Kusurkar et al., 2013) and the results of the study also showed that perceived academic competence and perceived academic self-determination positively influenced autonomous academic motivation (Fortier et al., 1995). Previous studies showed that motivation and learning are important. Factors such as a good relationship between teacher and student, transmission of messages clearly, group work, offering options, planning attractive and interesting learning activities, providing important and valuable learnings for the students, support and encourage the motivation and learning of the students (Saeed \& Zyngier, 2012). In this context, it can be said that the use of motivational enhancing elements in learning environments will positively affect students' attitudes towards learning. Therefore, as the motivation variable on learning is important, it is thought that the examination of the relationship between motivation and attitude towards learning will contribute to the literature significantly.

In this research, the following questions were asked.

- Do university students' attitudes toward learning differ significantly according to gender?

- Do university students' attitudes toward learning differ significantly according to grade level?

- Do university students' attitudes toward learning differ significantly according to school type?

- Do the academic motivations of university students differ significantly according to gender?

- Do the academic motivations of university students differ significantly according to grade level?

- Do the academic motivations of university students differ significantly according to school type?

- Is there a significant correlation between university students ' attitudes towards learning and academic motivations? 


\section{METHOD}

\section{Research Design}

The research is in the survey design. A survey design provides a quantitative or numeric description of trends, attitudes, or opinions of a population by studying a sample of that population (Creswell, 2013). The study, as it provided quantitative or numerical description of trends, attitudes, or opinions in the population through studies on a sample selected from the population, was designed as survey model.

\section{Population and Sample}

The population of the study consisted of university students at a state university in Turkey. The sample is composed of 260 university students determined by stratified sampling method from the related university students. The distribution of the sample according to the variables is given in Table 1 .

Table 1

Distribution of the sample by variables

\begin{tabular}{|c|c|c|c|}
\hline & Variables & $\mathrm{N}$ & $\%$ \\
\hline \multirow{3}{*}{ Gender } & Female & 114 & 43.8 \\
\hline & Male & 146 & 56.2 \\
\hline & Total & 260 & 100.0 \\
\hline \multirow{5}{*}{ Grades } & Freshman year & 111 & 42.7 \\
\hline & Sophomore year & 64 & 24.6 \\
\hline & Junior year & 43 & 16.5 \\
\hline & Senior year & 42 & 16.2 \\
\hline & Total & 260 & 100.0 \\
\hline \multirow{3}{*}{ School Type } & Faculty & 171 & 65.8 \\
\hline & Vocational School of Higher Education & 89 & 34.2 \\
\hline & Total & 260 & 100.0 \\
\hline
\end{tabular}

\section{Instruments}

In the research process, data were obtained by applying two different scales to determine student attitudes toward learning and academic motivation.

The Scale of Attitudes Towards Learning: The Scale of Attitudes Towards Learning was developed by Kara (2010). The five point Likert scale composed of 40 items and 4 subdimensions of "nature of learning (7 items)", "openness (11 items)", "anxiety (13 items)" and "expectation (9 items)". For the scale, exploratory factor analysis was performed first and the four-dimensional structure revealed $58.36 \%$ of the total variance. Confirmatory factor analysis was also performed for this study. According to the CFA, the results are as follows: $\chi^{2} / \mathrm{sd}=2,232, \mathrm{RMSEA}=.067, \mathrm{SRMR}=.055, \mathrm{CFI}=.90$, $\mathrm{AGFI}=.90, \mathrm{NFI}=.91$. The values obtained show acceptable fit according to the reference values. The Cronbach Alpha reliability coefficient for the complete scale is .77.

Academic Motivation Scale: The scale was developed by Vallerand et al. (1992) and the adaptation to Turkish was done by Ünal- Karagüven (2012). Seven point Likert scale 
composed of 28 items and subdivided into 7 subscales of "Intrinsic motivation to know (4 items)", "Intrinsic motivation to accomplish (4 items)", "Intrinsic motivation to experience stimulation (4 items)", Extrinsic motivation identified regulation (4 items), "Extrinsic motivation introjected regulation " (4 items), "Extrinsic motivation external regulation (4 items)" and "Amotivation (4 items)". As a result of the exploratory factor analysis for the scale, it was found that the seven-dimensional structure revealed $58.06 \%$ of the total variance. According to the CFA, the results are as follows: $\chi^{2} / \mathrm{sd}=3.094$, $\mathrm{RMSEA}=.073, \mathrm{SRMR}=.065, \mathrm{CFI}=.94, \mathrm{AGFI}=.81, \mathrm{NFI}=.91$. The values obtained show acceptable fit according to the reference values. The Cronbach Alpha reliability coefficient for the complete scale is .87 .

\section{Data Analysis}

In order to determine whether there is a difference of the university students' attitudes towards learning and academic motivations in terms of gender, class and school type, it was first tested whether the data showed a normal distribution. As it was determined that the data are not normally distributed, The Mann-Whitney $U$ test was used to compare the scores of two different participant groups on a continuous variable from the nonparametric test, and the Kruskal Wallis test was used to compare scores of two groups. In addition, in the analysis of the relationship between two continuous variables, Spearman rank order correlation coefficient was calculated.

\section{FINDINGS}

The results of the Mann Whitney $U$ test on whether the attitudes of university students towards learning differ according to the gender variable are given in Table 2.

Table 2

The results of the Mann Whitney U test on whether the attitudes of university students towards learning differ according to the gender variable

\begin{tabular}{|c|c|c|c|c|c|c|c|}
\hline Sub-Dimensions & Gender & $\mathrm{N}$ & Mean Rank & Sum of Ranks & $\mathrm{U}$ & $\mathrm{Z}$ & $\mathrm{p}$ \\
\hline \multirow{2}{*}{ Nature of Learning } & Female & 114 & 140.56 & 16024.00 & \multirow{2}{*}{7175} & \multirow{2}{*}{-1.914} & \multirow{2}{*}{.056} \\
\hline & Male & 146 & 122.64 & 17906.00 & & & \\
\hline \multirow{2}{*}{ Openness } & Female & 114 & 142.28 & 16219.50 & \multirow{2}{*}{6979.5} & \multirow{2}{*}{-2.235} & \multirow{2}{*}{.025} \\
\hline & Male & 146 & 121.30 & 17710.50 & & & \\
\hline \multirow{2}{*}{ Anxiety } & Female & 114 & 128.80 & 14683.00 & \multirow{2}{*}{8128} & \multirow{2}{*}{-.323} & \multirow{2}{*}{.747} \\
\hline & Male & 146 & 131.83 & 19247.00 & & & \\
\hline \multirow{2}{*}{ Expectation } & Female & 114 & 143.59 & 16369.50 & \multirow{2}{*}{6829.5} & \multirow{2}{*}{-2.486} & \multirow{2}{*}{.013} \\
\hline & Male & 146 & 120.28 & 17560.50 & & & \\
\hline \multirow{2}{*}{ Total } & Female & 114 & 142.33 & 16226.00 & \multirow{2}{*}{6973} & \multirow{2}{*}{-2.243} & \multirow{2}{*}{.025} \\
\hline & Male & 146 & 121.26 & 17704.00 & & & \\
\hline
\end{tabular}

Table 2 shows that at "Openness", "Expectations" sub-dimensions and "Total", the attitudes of university students towards learning differ according to the gender variable. It is understood that there is a significant difference in favor of female students, in both sub-dimensions and in total, where a significant difference found. $\left[\left(U_{\text {Openness }}=6979.5\right.\right.$, $\left.\mathrm{p}<.05),\left(\mathrm{U}_{\text {Expectations }}=6829.5, \mathrm{p}<.05\right),\left(\mathrm{U}_{\text {Total }}=6973, \mathrm{p}<.05\right)\right]$. The results of the Kruskal Wallis test on whether the university students' attitudes towards learning differ according to grade variables are given in Table 3. 
Table 3

The results of the Kruskal Wallis test on whether the university students' attitudes towards learning differ according to grade variable

\begin{tabular}{|c|c|c|c|c|c|c|c|c|}
\hline \multirow{21}{*}{ 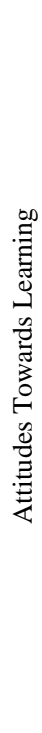 } & $\begin{array}{l}\text { Sub- } \\
\text { Dimension }\end{array}$ & Variable- Class & $\mathrm{N}$ & $\begin{array}{l}\text { Mean } \\
\text { Rank }\end{array}$ & $\boldsymbol{X}^{2}$ & df & $\mathrm{p}$ & $\begin{array}{l}\text { Significant } \\
\text { Difference }\end{array}$ \\
\hline & & Freshman year & 111 & 124,95 & \multirow{4}{*}{6.185} & \multirow{4}{*}{3} & \multirow{4}{*}{.103} & \\
\hline & Nature of & Sophomore year & 64 & 130,84 & & & & \\
\hline & Learning & Junior year & 43 & 155,14 & & & & \\
\hline & & Senior year & 42 & 119,43 & & & & \\
\hline & \multirow{4}{*}{ Openness } & Freshman year & 111 & 113,25 & \multirow{4}{*}{10.763} & \multirow{4}{*}{3} & \multirow{4}{*}{.013} & \multirow{4}{*}{$1<3$} \\
\hline & & Sophomore year & 64 & 143,31 & & & & \\
\hline & & Junior year & 43 & 149,40 & & & & \\
\hline & & Senior year & 42 & 137,23 & & & & \\
\hline & \multirow{4}{*}{ Anxiety } & Freshman year & 111 & 128,88 & \multirow{4}{*}{2.300} & \multirow{4}{*}{3} & \multirow{4}{*}{.512} & \\
\hline & & Sophomore year & 64 & 141,38 & & & & \\
\hline & & Junior year & 43 & 119,66 & & & & \\
\hline & & Senior year & 42 & 129,31 & & & & \\
\hline & \multirow{4}{*}{ Expectation } & Freshman year & 111 & 116,32 & \multirow{4}{*}{6.992} & \multirow{4}{*}{3} & \multirow{4}{*}{.072} & \\
\hline & & Sophomore year & 64 & 139,60 & & & & \\
\hline & & Junior year & 43 & 140,73 & & & & \\
\hline & & Senior year & 42 & 143,63 & & & & \\
\hline & \multirow{4}{*}{ Total } & Freshman year & 111 & 115,87 & \multirow{4}{*}{8.142} & \multirow{4}{*}{3} & \multirow{4}{*}{0.53} & \\
\hline & & Sophomore year & 64 & 141,93 & & & & \\
\hline & & Junior year & 43 & 148,21 & & & & \\
\hline & & Senior year & 42 & 133,61 & & & & \\
\hline
\end{tabular}

** Significance value was calculated as .008 after Bonferroni correction $(0.05 / 6=0.008)$ and significance values were interpreted according to this value.

Table 3 shows that university students' attitudes towards learning are significantly

different only in "Openness" sub-dimension according to class variable $\left(X^{2}{ }_{(3)}=10.763\right.$, $\mathrm{p}<.05)$. According to the Mann Whitney $U$ test to determine for which group the difference is in favor of, it has been determined that this difference is in favor for junior year students between freshman year students and senior year students. The results of the Mann Whitney $U$ test on whether the attitudes of university students towards learning differ according to school type variable are given in Table 4. 
Table 4

Mann Whitney U Test results on whether the attitude towards learning differs according to the faculty /vocational school of higher education variable

\begin{tabular}{|c|c|c|c|c|c|c|c|}
\hline Sub-Dimensions & School Type & $\mathrm{N}$ & Mean Rank & Sum of Ranks & $\mathrm{U}$ & $\mathrm{Z}$ & $\mathrm{p}$ \\
\hline \multirow[b]{2}{*}{$\begin{array}{l}\text { Nature of } \\
\text { Learning }\end{array}$} & Faculty & 171 & 122.82 & 21003 & \multirow[b]{2}{*}{6297} & \multirow[b]{2}{*}{-2.291} & \multirow[b]{2}{*}{.062} \\
\hline & $\begin{array}{l}\text { Vocational School of } \\
\text { Higher Education }\end{array}$ & 89 & 145.25 & 12927 & & & \\
\hline \multirow[b]{2}{*}{ Openness } & Faculty & 171 & 128.54 & 21979.5 & \multirow[b]{2}{*}{7273.5} & \multirow[b]{2}{*}{-.585} & \multirow[b]{2}{*}{.559} \\
\hline & $\begin{array}{l}\text { Vocational School of } \\
\text { Higher Education }\end{array}$ & 89 & 134.28 & 11950.5 & & & \\
\hline \multirow[b]{2}{*}{ Anxiety } & Faculty & 171 & 130.52 & 22319.5 & \multirow[b]{2}{*}{7605.5} & \multirow[b]{2}{*}{-.007} & \multirow[b]{2}{*}{.994} \\
\hline & $\begin{array}{l}\text { Vocational School of } \\
\text { Higher Education }\end{array}$ & 89 & 130.46 & 11610.5 & & & \\
\hline \multirow[b]{2}{*}{ Expectation } & Faculty & 171 & 130.35 & 22290 & \multirow[b]{2}{*}{7584} & \multirow[b]{2}{*}{-.044} & \multirow[b]{2}{*}{.965} \\
\hline & $\begin{array}{l}\text { Vocational School of } \\
\text { Higher Education }\end{array}$ & 89 & 130.79 & 11640 & & & \\
\hline \multirow[b]{2}{*}{ Total } & Faculty & 171 & 128.14 & 21912.5 & \multirow[b]{2}{*}{7206.5} & \multirow[b]{2}{*}{-.701} & \multirow[b]{2}{*}{.483} \\
\hline & $\begin{array}{l}\text { Vocational School of } \\
\text { Higher Education }\end{array}$ & 89 & 135.03 & 12017.5 & & & \\
\hline
\end{tabular}

Table 4 shows that in all sub-dimensions and in total, there is no difference according to the school type variable of the attitudes of university students towards learning. [ $\left(\mathrm{U}_{\text {Nature }}\right.$ of learning $=6297.5, \mathrm{p}>.05),\left(\mathrm{U}_{\text {Openness }}=7273.5, \mathrm{p}>.05\right), \quad\left(\mathrm{U}_{\text {Anxiety }}=7605.5, \mathrm{p}>.05\right)$, $\left.\left(\mathrm{U}_{\text {Expectation }}=7584, \mathrm{p}>.05\right),\left(\mathrm{U}_{\text {Total }}=7206.5, \mathrm{p}>.05\right)\right]$. The results of the Mann Whitney $\mathrm{U}$ test on whether the attitudes of university students towards learning differ according to gender variable are given in Table 5.

Table 5

Mann Whitney U test results on whether academic motivations of university students differ according to gender variable

\begin{tabular}{|c|c|c|c|c|c|c|c|}
\hline Sub-dimensions & Gender & $\mathrm{N}$ & Mean Rank & Sum of Ranks & $\mathrm{U}$ & $\mathrm{Z}$ & $\mathrm{p}$ \\
\hline 1.Intrinsic & Female & 114 & 141.86 & 16172 & \multirow{2}{*}{7027} & \multirow{2}{*}{-2.153} & \multirow{2}{*}{.031} \\
\hline Motivation & Male & 146 & 121.63 & 17758 & & & \\
\hline 2.Extrinsic & Female & 114 & 141.17 & 16093 & \multirow{2}{*}{7106} & \multirow{2}{*}{-2.022} & \multirow{2}{*}{.043} \\
\hline Motivation & Male & 146 & 122.17 & 17837 & & & \\
\hline \multirow{2}{*}{ 3.Amotivation } & Female & 114 & 112.43 & 12817.5 & \multirow{2}{*}{6262.5} & \multirow{2}{*}{-3.441} & \multirow{2}{*}{.001} \\
\hline & Male & 146 & 144.61 & 21112.5 & & & \\
\hline \multirow{2}{*}{ Total } & Female & 114 & 142.35 & 16228 & \multirow{2}{*}{6971} & \multirow{2}{*}{-2.246} & \multirow{2}{*}{.025} \\
\hline & Male & 146 & 121.25 & 17702 & & & \\
\hline
\end{tabular}

Table 5 shows that the academic motivation of university students differs at 'Intrinsic motivation, extrinsic motivation, amotivation and in total according to gender variable. It is understood that there is a significant difference in favor of female students, in both sub-dimensions and in total, where a significant difference found $\left[\left(\mathrm{U}_{\text {Intrinsic Motivation }}=\right.\right.$ 7027, $\mathrm{p}<.05),\left(\mathrm{U}_{\text {Extrinsic Motivation }}=7106, \mathrm{p}<.05\right),\left(\mathrm{U}_{\text {Amotivation }}=6262.5, \mathrm{p}<.05\right)\left(\mathrm{U}_{\text {Total }}=6971\right.$, $\mathrm{p}<.05)]$. In the amotivation sub dimension, the mean order of the female students is less than male students' and this shows that the results are in favor of females. The results of the Mann Whitney U test on whether academic motivations of university students vary according to the class variable are given in Table 6. 
Table 6

Mann Whitney $U$ test results on whether academic motivations of university students vary according to the class variable

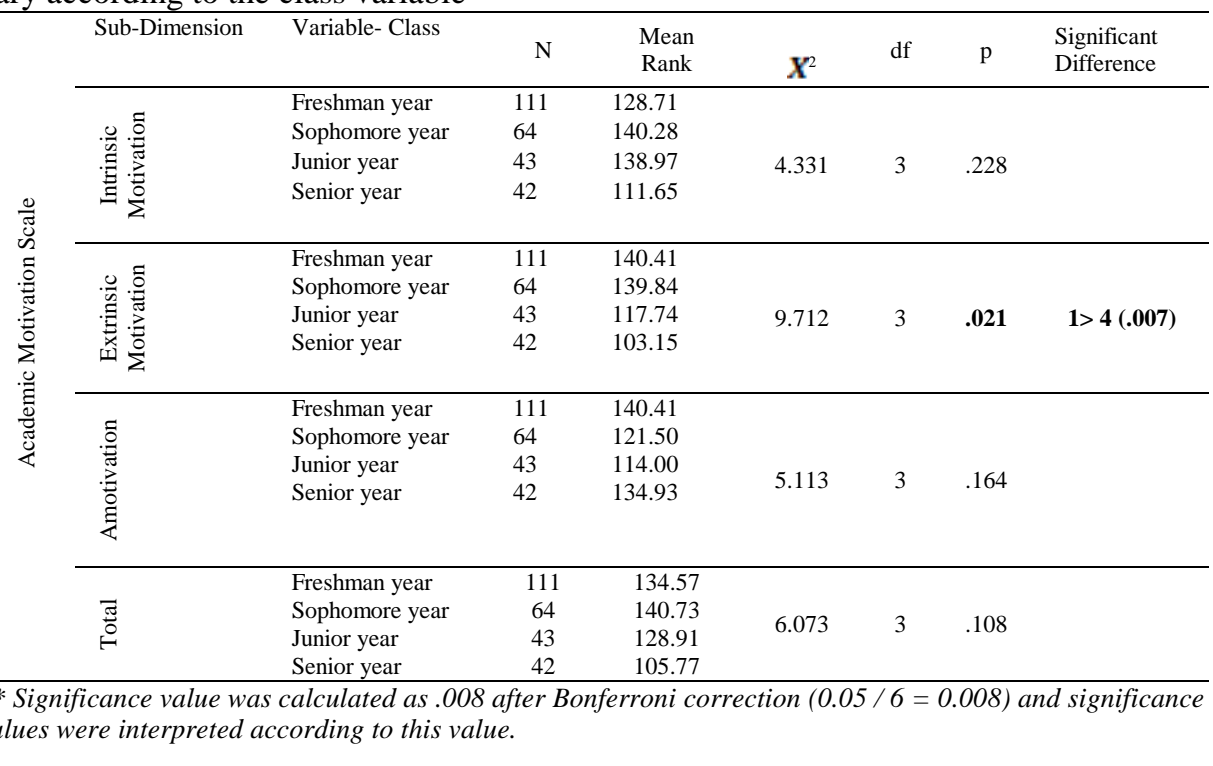

Table 6 shows that the academic motivation of university students is significantly different only in the sub-dimension of "Extrinsic Motivation" according to the class variable $\left(X^{2}{ }_{(3)}=9.712, \mathrm{p}<.05\right)$. According to the Mann Whitney $\mathrm{U}$ test to determine for which group the difference is in favor of, it has been determined that this difference is in favor of freshman year students between freshman year students and senior year students. The results of the Mann Whitney $U$ test on whether academic motivations of university students vary according to the school type variable are given in Table 7 .

Table7

Mann Whitney U Test results on whether academic motivations differs according to the faculty / vocational school of higher education variable

\begin{tabular}{|c|c|c|c|c|c|c|c|}
\hline Sub-Dimensions & School Type & $\mathrm{N}$ & $\begin{array}{l}\text { Mean } \\
\text { Rank }\end{array}$ & $\begin{array}{l}\text { Sum of } \\
\text { Ranks }\end{array}$ & $\mathrm{U}$ & $\mathrm{Z}$ & $\mathrm{p}$ \\
\hline \multirow[b]{2}{*}{$\begin{array}{l}\text { 1.Intrinsic } \\
\text { Motivation }\end{array}$} & \multirow{2}{*}{$\begin{array}{l}\text { Faculty } \\
\text { Vocational School of } \\
\text { Higher Education }\end{array}$} & 171 & 134.23 & 22954 & \multirow[b]{2}{*}{6971} & \multirow[b]{2}{*}{-1.110} & \multirow[b]{2}{*}{.267} \\
\hline & & 89 & 123.33 & 10976 & & & \\
\hline \multirow[b]{2}{*}{$\begin{array}{l}\text { 2.Extrinsic } \\
\text { Motivation }\end{array}$} & \multirow{2}{*}{$\begin{array}{l}\text { Faculty } \\
\text { Vocational School of } \\
\text { Higher Education }\end{array}$} & 171 & 131.16 & 22428 & \multirow[b]{2}{*}{7497} & \multirow[b]{2}{*}{-.196} & \multirow[b]{2}{*}{.845} \\
\hline & & 89 & 129.24 & 11502 & & & \\
\hline \multirow[b]{2}{*}{ 3.Amotivation } & Faculty & 171 & 128.77 & 22019.5 & \multirow[b]{2}{*}{7313.5} & \multirow[b]{2}{*}{-.517} & \multirow[b]{2}{*}{.605} \\
\hline & $\begin{array}{l}\text { Vocational School of } \\
\text { Higher Education }\end{array}$ & 89 & 133.83 & 11910.5 & & & \\
\hline \multirow[b]{2}{*}{ Total } & Faculty & 171 & 133.29 & 22792 & \multirow[b]{2}{*}{7133} & \multirow[b]{2}{*}{-.828} & \multirow[b]{2}{*}{.407} \\
\hline & $\begin{array}{l}\text { Vocational School of } \\
\text { Higher Education }\end{array}$ & 89 & 125.15 & 11138 & & & \\
\hline
\end{tabular}


Table 7 shows that there is no difference in academic motivations of university students in all sub-dimensions and in total, according to the school type variable $\left[\left(\mathrm{U}_{\text {Intrinsic Motivation }}\right.\right.$ $=6971, \mathrm{p}>.05),\left(\mathrm{U}_{\text {Extrinsic Motivation }}=7497, \mathrm{p}>.05\right),\left(\mathrm{U}_{\text {Amotivation }}=7313.5, \mathrm{p}>.05\right),\left(\mathrm{U}_{\text {Total }}=\right.$ $7133, \mathrm{p}>.05)]$. The results of the correlation analysis for determining the relationship between university students' attitudes towards learning and their academic motivations are given in table 8 .

Table 8

The correlation analysis for determining the relationship between university students' attitudes towards learning and their academic motivations

\begin{tabular}{llllll}
\hline Sperman's rho & $\begin{array}{l}\text { Attitude towards } \\
\text { learning }\end{array}$ & $\begin{array}{l}\text { Academic } \\
\text { motivation }\end{array}$ & $\begin{array}{l}\text { Intrinsic } \\
\text { Motivation }\end{array}$ & $\begin{array}{l}\text { Extrinsic } \\
\text { Motivation }\end{array}$ & Amotivation \\
\hline $\begin{array}{l}\text { Attitude towards } \\
\text { learning }\end{array}$ &, $426^{* *}$ & $.408^{* *}$ & $.378^{* *}$ & $-.252^{* *}$ \\
$\begin{array}{l}\text { Academic motivation } \\
\text { Intrinsic Motivation }\end{array}$ &, $426^{* *}$ & & $.924^{* *}$ & $.875^{* *}$ & $-.225^{* *}$ \\
Extrinsic Motivation & $.378^{* *}$ & $.924^{* *}$ & & $.637^{* *}$ & $-.213^{* *}$ \\
Amotivation & $-.252^{* *}$ & $.875^{* *}$ & $.637^{* *}$ & & $-.169^{* *}$ \\
\hline
\end{tabular}

Table 8 shows that, as a result of the correlation analysis for determining the relationship between the attitudes of university students towards learning and their academic motivations, it is seen that there is a moderate and positive correlation $(\mathrm{r}=$ $.426, \mathrm{n}=260, \mathrm{p}<.001$ ) between the two variables. In addition, when the results of the correlation analysis on the sub-dimensions of academic motivation were examined, it was found that there was a high and positive correlation between intrinsic and extrinsic motivation and academic motivation $\left(\mathrm{r}_{\text {intrinsic motivation }}=.924, \mathrm{n}=260, \mathrm{p}<.001 ; \mathrm{r}_{\text {extrinsic }}\right.$ motivation $=.875, \mathrm{n}=260, \mathrm{p}<.001)$ and it was also found that there is a low and negative correlation between amotivation and academic motivation $(r=-.225, n=260, p<.001)$. It is understood that there is a low and negative correlation between intrinsic motivation and amotivation $\left(\mathrm{r}_{\text {intrinsic motivation }}=-.213, \mathrm{n}=260, \mathrm{p}<.001\right.$ ) and there is also a low and negative correlation between extrinsic motivation and amotivation $\left(\mathrm{r}_{\text {extrinsic motivation }}=\right.$ $.169, \mathrm{n}=260, \mathrm{p}<.001)$. The decision on the moderate relation is given by the correlation coefficient values specified by Cohen (1988). Cohen (1988) mentions moderate relation for the values between .30 and .49 . According to these results, university students with high attitudes towards learning show high academic motivation.

\section{DISCUSSION AND CONCLUSION}

The following results have been achieved according to the results of this study, which examines the relationship between university students' attitudes towards learning and their academic motivation

It was found that the attitudes of university students towards learning differ significantly in favor of females in openness and expectation sub dimensions and in total according to gender variable. Similar results show that female students use more open learning strategies than male students (Carr \& Jessup, 1997) and that females use more learning strategies than men (Sheorey, 1999) in language lessons. Phakiti (2003), on the other hand, has found that males use more learning strategies. Obtaining different results may be due to the fact that the psychological characteristics of male and female students, their social environment and their educational environment are different. 
It was found that the university students ' academic motivations significantly differ in favor of female students in 'intrinsic motivation', 'extrinsic motivation', 'amotivation' and in 'total' according to gender variable. It is expressed as positive that the mean order of the female students is being low. In some studies on motivation, it was also concluded that the motivations of females were higher than males (Awan et al., 2011; Brouse et al., 2010; Eymur \& Geban, 2011; Gömleksiz \& Serhatlığlu, 2013; Hegarty, 2010; Roohi \& Asayesh, 2012; Sikhwari, 2014). Vecchione et al. (2014) concluded that the predictive power of the academic achievement for the intrinsic motivation is stronger for the females. Bear et al. (2017) found that female students had a higher level of intrinsic motivation than males and had a lower level of extrinsic motivation.

According to the class variable of university students ' attitudes towards learning, only in the openness sub dimension, there was a significant difference in favor of the junior year students between the junior and freshman year students. This result shows that junior year students are more open to learning than freshman year students. In this case, it gives clues about the fact that junior year students are more conscious about learning.

According to the class variable of academic motivations of the university students, only in the extrinsic motivation sub dimension, there was a significant difference in favor of the freshman year students between freshmen and senior year students. There are research results that support this result (Brouse et al., 2010; Eymur \& Geban, 2011; Gömleksiz \& Serhatlıoglu, 2013). In the related researches, it has also been stated that as the class level increases, the motivation of the students decreases. Gillet et al. (2012) also point out in a study that as age increases, extrinsic motivation decreases and this results support meaningful results of our study. This is explained by the fact that the students who are new to the university education are more excited and enthusiastic.

It was found that the attitudes of university students towards learning and their academic motivation did not differ according to the Faculty/Vocational school variable. This result indicates that the faculty / vocational school type variable has less contribution to motivation and learning attitudes than other variables.

As a result of correlation analysis to determine the relationship between university students ' attitudes towards learning and academic motivations it was determined that there was a moderate and positive correlation between the two variables. Pintrich and Schunk (2002) also found that motivation influences learning and performance and the students' learning situations affect their motivations. Tella (2007) describes this as an important aspect of effective learning for motivating students. He also emphasizes that a satisfactory learning cannot occur in the absence of sufficient motivation. As it is considered that the motivational beliefs of the students and the learning strategies are related to the participation in the learning, it can be said that the motivated students will participate more effectively in the learning process.

It is observed that there is a high level and positive correlation between intrinsic and extrinsic motivation and academic motivation and that there is a low and negative correlation between amotivation and academic motivation. It was concluded that there was a low and negative correlation between intrinsic motivation and amotivation and extrinsic motivation and amotivation. A similar result was obtained as a result of the 
research carried out by Robinson (2003). In the related research, negative correlation was found between amotivation and success. This results show that the amotivation of the students will decrease as their motivation increases and likewise their intrinsic and extrinsic motivation will decrease as their amotivaiton increases.

There are researches that supports the results that intrinsic and extrinsic motivation is highly positively related to academic motivation (Afzal et al., 2010; Peklaj \& Levpušček, 2006). Goldberg and Cornell (1998) and Mnyandu (2001) found a significant positive relationship between intrinsic motivation and achievement and learner performance. Research results have also been found in the literature that there is a positive relationship between academic achievement and intrinsic motivation (Corpus et al., 2009; Law et al., 2012; Lee et al., 2010). Higher successes of students with intrinsic motivation can be explained by having lower levels of anxiety and having higher perceptions of competence. Considering that student motivation is a prerequisite for academic performance (Masitsa, 2008), it can be said that this result is also important for students' academic performance. Ayub (2010) states that intrinsic and extrinsic motivation affect the achievements and goals of the students. Bear et al. (2017) emphasize that intrinsic and extrinsic motivation affect the performances of the students. Ning and Downing (2010) and Afzal et al. (2010) found a positive relationship between intrinsic motivation and academic performance. Robbins et al. (2004) found a similar result. In the relevant study, it was concluded that intrinsic and extrinsic motivation were a significant predictor of GPA (grade point average) of the students. Turner et al. (2009) concluded in another study that increased self-efficacy and intrinsic motivation scores were positively associated with academic performance.

As a result, it can be said that there is a positive relationship between attitudes towards learning and motivation; female students have more academic motivation than male students; as the class level increases, motivation decreases and that female students are more open to learn and have more expectations than male students. Based on the findings obtained from the study, the reason why male students ' attitudes towards learning and motivation are lower than female students can be investigated by qualitative studies. In addition, in terms of class variable, the reasons for the decrease of the motivation of the students towards the last grades can be investigated by doing causal comparative research.

\section{Acknowledge}

This study was presented at the First International Unlimited Education and Research Symposium (24-26 April 2017).

\section{REFERENCES}

Afzal, H.; Ali, I.; Khan, M. A. \& Hamid, K. (2010). A study of university students' motivation and its relationship with their academic performance. International Journal of Business and Management, 5(4), 80-89. doi:10.5539/ijbm.v5n4p80

Ames, C. (1992). Classrooms: Goals, structures, and student motivation. Journal of Educational Psychology, 84, 261-271. 
Amrai, K.; Motlagh, S. E.; Zalani, H. A. \& Parhon, H. (2011). The relationship between academic motivation and academic achievement students. Procedia Social and Behavioral Sciences, 15, 399-402. doi: 10.1016/j.sbspro.2011.03.111

Awan R.U.N.; Noureen G. \& Naz, A. (2011). A study of relationship between achievement motivation, self-concept and achievement in English and Mathematics at secondary level. International Education Studies, 4(3): 72-79. doi: 10.5539/ies.v4n3p72

Ayub, N. (2010). Effect of intrinsic and extrinsic motivation on academic performance. Pakistan Business Review, 8, 363-372.

Bear, G. G.; Slaughter, J. C.; Mantz, L. S. \& Farley-Ripple, E. (2017). Rewards, praise, and punitive consequences: Relations with intrinsic and extrinsic motivation. Teaching and Teacher Education, 65, 10-20.

Benabou, R., \& Tirole, J. (2003). Intrinsic and extrinsic motivation. The Review of Economic Studies, 70(3), 489-520. doi: 10.1111/1467-937X.00253

Biggs, J. B. (1987). Student approaches to learning and studying. Retrieved 10 May, 2018 from https://files.eric.ed.gov/fulltext/ED308201.pdf

Brouse, C. H.; Basch, C. E.; LeBlanc, M.; McKnight, K. R. \& Lei, T. (2010). College students' academic motivation: Differences by gender, class, and source of payment. College Quarterly, 13(1), 1-10.

Bye, D.; Pushkar, D. \& Conway, M. (2007). Motivation, interest, and positive affect in traditional and nontraditional undergraduate students. Adult Education Quarterly, 57(2). 141-158. doi: 10.1177/0741713606294235

Carlton, M. P., \& Winsler, A. (1998). Fostering intrinsic motivation in early childhood classrooms. Early Childhood Education Journal, 25(3), 159-66. doi: 10.1023/A:1025601110383

Carr, M., \& Jessup, D. (1997). Gender differences in first-grade mathematics strategy use: Social metacognitive influences. Journal of Educational Psychology, 89(2), 318328. doi: 10.1037/0022-0663.89.2.318

Cohen, J. W. (1988). Statistical power analysis for the behavioral sciences (2nd. ed.). Hilldsdale, NJ: Lawrence Erlbaum Associates.

Corpus, J. H.; McClintic-Gilbert, M. S. \& Hayenga, A. O. (2009). Within-year changes in children's intrinsic and extrinsic motivational orientations: Contextual predictors and academic outcomes. Contemporary Educational Psychology, 34, 154-166.

Creswell, J.W. (2013) Research design: Qualitative, quantitative, and mixed methods approaches. (4th ed.). London: SAGE Publications.

Daniels, E. (2010). Creating motivating learning environment: What we can learn from researchers and students. The English Journal, 100(1), 25-29.

Deci, E. L., \& Ryan, R. M. (1985). Intrinsic motivation and self-determination in human behavior. New York, NY: Plenum Press. 
Deci, E. L., \& Ryan, R. M. (2000). Self-determination theory and the facilitation of intrinsic motivation, social development, and well-being. American Psychologist, 55, 68-78. doi: 10.1037/0003-066X.55.1.68

Deci, E.L.; Vallerand, R.J. ; Pelletier, L.G. \& Ryan, R.M. (1991). Motivation and education: The self-determination perspective. Educational Psychologist, 26(3\&4), 326-346.

Demir, M. K., \& Budak, H. (2016). The relationship between self-regulating, motivation and metacognitive skills and mathematics success of 4th grade students. The Journal of Buca Faculty of Education, 41, 30-41.

Eymur, G., \& Geban, Ö. (2011). An investigation of relationship between motivation and academic achievement of pre-service chemistry teachers. Education and Science, 36(161), 246-255.

Fairchild, A.J.; Horst, S. J.; Finney, S. J. \& Barron, K. E. (2005). Evaluating the existing and new evidence for the academic motivation scale. Contemporary Educational Psychology, 30(3), 331-358. doi: 10.1016/j.cedpsych.2004.11.001

Forsyth, D. R., \& McMillan, J. H. (1991). Practical proposals for motivating students. New Directions for Teaching and Learning, 45, 53-65. doi: 10.1002/t1.37219914508

Fortier, M. S.; Vallerand, R. J. \& Guay, F. (1995). Academic motivation and school performance: toward a structural model. Contemporary Educational Psychology, 20(3), 257-274. doi: 10.1006/ceps.1995.1017

Gillet, N.; Vallerand, R. J. \& Lafrenière, M. K. (2012). Intrinsic and extrinsic school motivation as a function of age: The mediating role of autonomy support. Social Psychology of Education, 15(1), 77-95.

Goldberg, M. D., \& Cornell, D. I. (1998). The influence of intrinsic motivation and selfconcept on academic achievement in second-and third-grade students. Journal for the Education of the Gifted, 21(2), 179-205. doi: 10.1177/016235329802100204

Gotfried, A. E. (1990). Academic intrinsic motivation in young elementary school children. Journal of Educational Psychology, 82(3), 525-538. doi: 10.1037/00220663.82 .3 .525

Gömleksiz, M. N., \& Serhatlığlu, B. (2013). Prospective teachers' perceptions of academic motivation levels. The Journal of Turkish Social Research, 17(3), 99-127.

Green, J.; Nelson, G.; Martin, A. J. \& Marsh, H. (2006). The causal ordering of selfconcept and academic motivation and its effect on academic achievement. International Education Journal, 7(4), 534-546.

Hegarty, N. (2010). Application of the academic motivation scale to graduate school student. The Journal of Human Resource and Adult Learning, 6(2), 48-55.

Kara, A. (2010). The development of the scale of attitudes towards learning. Electronic Journal of Social Sciences, 9(32), 49-62. 
Kusurkar, R. A.; Croiset, G.; Galindo-Garré, F. \& Cate, O. T. (2013). Motivational profiles of medical students: Association with study effort, academic performance and exhaustion. BMC Medical Education, 13, 87. doi: 10.1186/1472-6920-13-87

Lai, E. R. (2011). Motivation: A literature review - research report. Retrieved from https://images.pearsonassessments.com/images/tmrs/Motivation_Review_final.pdf

Law, W.; Elliot, A. J. \& Murayama, K. (2012). Perceived competence moderates the relation between performance-approach and performance-avoidance goals. Journal of Educational Psychology, 104(3), 806-819.

Lee, J. Q.; McInerney, D. M.; Liem, G. A. D. \& Ortiga, Y. P. (2010). The relationship between future goals and achievement goal orientations: An intrinsic-extrinsic motivation perspective. Contemporary Educational Psychology, 35(4), 264-279.

Lei, S. A. (2010). Intrinsic and extrinsic motivation: Evaluating benefits and drawbacks from college instructors' perspectives. Journal of Instructional Psychology, 37(2), 153-160.

Lepper, M. R. (1988). Motivational considerations in the study of instruction. Cognition and Instruction, 5(4), 289-309. Retrieved from http://www.jstor.org/stable/3233574

Linnenbrink, E. A., \& Pintrich, P. R. (2002). Motivation as an enabler for academic success. The School Psychology Review, 31(3), 313-327.

Lindner, R. W., \& Harris, B. R. (1998). Self-regulated learning in education majors. Journal of General Education, 47(1), 63-78. Retrieved from http://www.jstor.org/stable/27797364

Lumsden, L. S. (1994). Student motivation to learn. ERIC Digest, 92. [ED370200].

Masitsa G. (2008). Tracing the development of poor student motivation and performance in township secondary schools. Africa Education Review, 5(1), 84-108. doi: 10.1080/18146620802144826

Merlin, R. (2003). Students' motivation to learn: Considerations for elementary teachers. Williamsburg, VA: College of William \& Mary.

Mnyandu P. T. (2001). The relations between self-determination, achievement motivation and academic achievement. (Master thesis, Pretoria: University of South

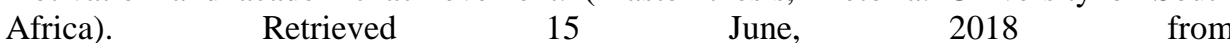
http://uir.unisa.ac.za/bitstream/handle/10500/2491/dissertation_mnyandu_pt.pdf;sequence=3

Ning, H. K., \& Downing, K. (2010). The reciprocal relationship between motivation and selfregulation: A longitudinal study on academic performance. Learning and Individual Differences, 20(6), 682-686.

Peklaj, C., \& Levpušček, M. P. (2006). Student motivation and academic success in relation to the quality of individual and collaborative work during a course in educational psychology. Annual 31 the ATEE conference Association of Teacher Education in Europe, University of Ljubljana. 
Phakiti, A. (2003). A closer look at the relationship of cognitive and metacognitive strategy use to EFL reading achievement test performance. Language Testing, 20(1), 2656. doi: 10.1191/02655322031t243oa

Pintrich, P. R. (2003). A motivational science perspective on the role of student motivation in learning and teaching contexts. Journal of Educational Psychology, 95(4), 667-686. doi: 10.1037/0022-0663.95.4.667

Pintrich P. R., \& Schunk, D. H. (2002). Motivation in education: Theory, research and application. $\left(2^{\text {nd }}\right.$. ed.). New Jersey: Pearson Education, Inc.

Pokay, P., \& Blumenfeld, P. C. (1990). Predicting achievement early and late in the semester: the role of motivation and use of learning strategies. Journal of Educational Psychology, 82(1), 41-50. doi: 10.1037/0022-0663.82.1.41

Pritchard, A. (2015). Ways of learning: Learning theories and learning styles in the classroom. (M. Çevikbaş \& S. Çevikbaş çev. Ed.). Ankara: Nobel. (Original work published 2009).

Ratelle, C. F.; Guay, F.; Vallerand, R. J.; Larose, S. \& Senécal, C. (2007). Autonomous, controlled, and amotivated types of academic motivation: A personoriented analysis. Journal of Educational Psychology, 99(4), 734-746. doi: 10.1037/0022-0663.99.4.734

Robbins, S. B.; Lauver, K.; Le, H.; Davis, D.; Langley, R. \& Carlstrom, A. (2004). Do psychosocial and study skill factors predict college outcomes? A meta-analysis. Psychological Bulletin, 130(2), 261-288

Robinson, N. M. (2003). Academic motivation and its relationship to personality variables and achievement (Unpublished doctoral dissertation). Southern Illinois University, Carbondale, IL, USA.

Roohi, G., \& Asayesh, H. (2012). Students' academic motivation in Golestan University of Medical Sciences. Iranian Journal of Medical Education, 12(3), 152-159.

Ryan, R. M., \& Deci, E. L. (2000). Intrinsic and extrinsic motivations: Classic definitions and new directions. Contemporary Educational Psychology, 25, 54-67.

Saeed, S., \& Zyngier, D. (2012). How motivation influences student engagement: A qualitative case study. Journal of Education and Learning, 1(2), 252-267.

Sakač, M. (2008). Some psychological factors of school achievement. Norma, 13, 2936.

Schunk, D. H. (2009). Learning theories: An educational perspectice. (M. Şahin çev. Ed.). Ankara: Nobel.

Sheorey, R. (1999). An examination of language learning strategy use in the setting of an indigenized variety of English. System, 27(2), 173-190. doi: 10.1016/S0346251X(99)00015-9 
Sikhwari, T. D. (2014). A Study of the relationship between motivation, self-concept and academic achievement of students at a university in Limpopo Province, South Africa. International Journal of Educational Sciences, 6(1), 19-25. doi:10.1080/09751122.2014.11890113

Song, H. D., \& Grabowski, B. L. (2006). Stimulating intrinsic motivation for problem solving using goal-oriented contexts and peer group composition. Educational Technology Research and Development, 54(5), 445-466. doi:10.1007/s11423-0060128-6

Tella A. (2007). The impact of motivation on student's academic achievement and learning outcomes in Mathematics among secondary school students in Nigeria. Eurasia Journal of Mathematics, Science and Technology Education, 3(2): 149-156. doi: 10.12973/ejmste/75390

Turner, E. A.; Chandler, M. \& Heffer, R. W. (2009). The influence of parenting styles, achievement motivation, and self-efficacy on academic performance in college students. Journal of College Student Development, 50(3), 337-346.

Ünal- Karagüven, M. H. (2012). The adaptation of academic motivation scale to Turkish. Educational Sciences: Theory\&Practice, 12(4), 2611-2618.

Vallerand, R. J.; Pelletier, L. G.; Blais, M. R.; Brière, N. M.; Senécal, C. \& Vallières, E. F. (1992). The academic motivation scale: a measure of intrinsic, extrinsic, and amotivation in education. Educational and Psychological Measurement, 52, 1003-1017.

Vallerand, R. J. ; Pelletier, L. G. ; Blais, M. R. ; Brière, N. M.; Senécal, C. \& Vallières, E. F. (1993). On the assessment of intrinsic, extrinsic and amotivation in education: Evidence on the concurrent and construct validity of the academic motivation scale. Educational and Psychological Measurement, 53, 159-172.

VanZile-Tamsen, C., \& Livingston. J. A. (1999). The differential impact of motivation on the self-regulated strategy use of high- and low-achieving college students. Journal of College Student Development, 40(1), 54-60.

Vecchione, M.; Alessandri, G. \& Marsicano, G. (2014). Academic motivation predicts educational attainment: Does gender make a difference? Learning and Individual Differences, 32(1), 124-131.

Velki, T. (2011). The correlation considering the degree of autonomous motivation, academic achievement and mental health. Croatian Journal of Education, 13(3), 56-87.

Woolfolk Hoy, A. (2015). Eğitim psikolojisi [Educational psychology]. (D. Özen çev.). İstanbul: Kaknüs.

Vanderstoep, S. W.; Pintrich, P. R. \& Fagerlin, A. (1996). Disciplinary differences in self-regulated learning in college students. Contemporary Educational Psychology, 21(4), 345-362. doi: 10.1006/ceps.1996.0026 